\title{
TATA KELOLA PERUSAHAAN DAN NILAI PERUSAHAAN
}

\author{
CYNTHIA LAVENIA YOHENDRA \\ MEINIE SUSANTY \\ Trisakti School of Management, Jl. Kyai Tapa No. 20, Grogol, Jakarta, 11440, Indonesia \\ cynlavenia@gmail.com
}

\begin{abstract}
The purpose of this research is to provide empirical evidence about the influence of managerial ownership, independent board of commissioners, audit committee, institutional ownership, size, debt to equity ratio, return on equity, liquidity and dividend payout ratio on Tobin's $Q$ as a measure of firm value. Sample of this research are 57 non financial companies listed in Indonesia Stock Exchange and the data were selected using purposive sampling method during the research period 2014 until 2016, thus totaled 171 data. Data were analyzed using multiple regression method. The empirical evidence of this research indicated that debt to equity ratio have significant influence with negative direction of the relationship while, return on equity and dividend payout ratio have significant influence on firm value with positive direction of the relationship. Besides that, managerial ownership, independent board of commissioners, audit committee, institutional ownership, size, and liquidity have no significant influence on firm value.
\end{abstract}

Keywords: Firm value, managerial ownership, independent board of commissioners, audit committee, institutional ownership, size

\begin{abstract}
Abstrak: Tujuan penelitian adalah untuk memberikan bukti empiris mengenai pengaruh kepemilikan manajerial, dewan komisaris independen, komite audit, kepemilikan institusional, ukuran perusahaan, debt to equity ratio, return on equity, likuiditas dan dividend payout ratio terhadap nilai perusahaan yang diukur dengan Tobin's Q. Sampel yang digunakan dalam penelitian ini adalah 57 perusahaan non keuangan yang terdaftar di Bursa Efek Indonesia yang diseleksi dengan metode purposive sampling selama periode penelitian dari 2014 sampai dengan 2016, dengan jumlah 171 data. Data dianalisis dengan menggunakan metode regresi berganda. Bukti empiris dari penelitian ini mengindikasikan bahwa debt to equity ratio berpengaruh signifikan terhadap nilai perusahaan dengan arah negatif, sementara return on equity dan dividend payout ratio berpengaruh signifikan terhadap nilai perusahaan dengan arah positif. Selain itu kepemilikan manajerial, dewan komisaris independen, komite audit, kepemilikan institusional, ukuran perusahaan dan likuiditas tidak memiliki pengaruh terhadap nilai perusahaan.
\end{abstract}

Kata kunci: Nilai perusahaan, kepemilikan manajerial, dewan komisaris independen, komite audit, kepemilikan institusional, ukuran perusahaan.

\section{PENDAHULUAN}

Nilai perusahaan merupakan faktor fundamental yang dapat dijadikan acuan bagi investor untuk memilih perusahaan yang tepat dalam melakukan investasi. Setiap perusahaan memiliki tujuan untuk memperoleh nilai perusahaan yang tinggi demi memberikan kesejahteraan bagi investor dan sebagai indikator kinerja perusahaan. Faktor-faktor seperti karakteristik perusahaan kinerja keuangan, kebijakan dividen, dan kebijakan 
hutang tidak terlepas dalam penciptaan nilai perusahaan. Nilai perusahaan yang tinggi juga merupakan hasil implementasi corporate Governance (CG) yang baik dalam perusahaan. Faktor-faktor tersebut saling terkait dalam menciptakan nilai perusahaan.

Moniaga (2013) menyatakan nilai perusahaan merupakan persepsi investor terhadap perusahaan yang memiliki hubungan terhadap harga saham. Harga saham yang tinggi merupakan pencapaian suatu perusahaan dalam mengelola kegiatan operasional dengan baik, semakin tinggi nilai perusahaan semakin tinggi tingkat pengembalian kepada investor. Naik turunnya harga saham tergantung dari kualitas laporan keuangan perusahaan yang menjadi pertimbangan investor dalam melakukan investasinya pada perusahaan.

Praktik CG merupakan salah satu alat untuk meningkatkan nilai perusahaan. Salah satunya praktik CG adalah komite audit yang berfungsi untuk mengawasi kualitas laporan keuangan. CG menjadi faktor penting bagi nilai perusahaan sebagai alat kontrol untuk menjaga keseimbangan antara kewajiban dan hak bagi pemegang saham, manager, kreditur, pemerintah, karyawan, dan stakeholder (Mukhtaruddin et al. 2014). CG merupakan faktor dalam menetapkan kebijakan atau keputusan yang akan diambil oleh perusahaan. Tata kelola yang baik pada suatu perusahaan akan berdampak positif terhadap kinerja suatu perusahaan yang akan menaikkan nilai perusahaan. Perusahaan menerapkan sistem GCG supaya kinerja perusahaan mengalami peningkatan lebih baik, yang selanjutnya akan dapat meningkatkan harga saham perusahaan sebagai indikator dari nilai perusahaan sehingga akan memaksimumkan nilai perusahaan (Carningsih 2009).

Ukuran perusahaan juga dapat memengaruhi nilai perusahaan dikarenakan semakin besar ukuran atau skala perusahaan maka semakin mudah perusahaan melakukan ekspansi usaha dan leluasa dalam mengelola aset sehingga skala usaha yang besar dapat memudahkan perolehan kredit baik dari pendanaan yang bersifat internal maupun eksternal (Dewi dan Wirajaya 2013). Kebijakan hutang juga dapat dihubungkan dengan nilai perusahaan. Kebijakan hutang terkait dengan jumlah perusahaan menggunakan pendanaan hutang. Pinjaman dana baik dari pihak internal atau eksternal perusahaan akan memperluas skala usaha dan memudahkan perusahaan melakukan pengembangan usaha. Proporsi hutang yang dikelola secara optimal diharapkan akan meningkatkan harga saham yang berakibat naiknya nilai perusahaan (Mardiyati et al. 2012).

Kinerja keuangan juga terkait dengan nilai perusahaan, seperti profitabilitas dan likuiditas dapat memengaruhi nilai perusahaan (Winarto 2015). Profitabilitas perusahaan yang semakin baik maka para stakeholders dan investor akan melihat kemampuan perusahaan menghasilkan laba dari penjualan dan investasi perusahaan (Prasetyorini 2013). Likuiditas adalah rasio yang digunakan untuk mengukur tingkat kemampuan suatu perusahaan dalam memenuhi kewajiban keuangan jangka pendek. Tingkat likuiditas yang tinggi menandakan perusahaan mampu memenuhi kewajiban jangka pendek (Rompas 2013). Kemampuan perusahaan dalam pemenuhan kewajiban jangka pendek menandakan perusahaan tersebut memiliki kondisi keuangan yang baik dan stabil.

Faktor lainnya yang memengaruhi nilai perusahaan adalah kebijakan dividen. Kebijakan dividen adalah pengembalian besarnya keuntungan yang akan diberikan kepada para pemegang saham (investor). Kebijakan keputusan pembagian dividen merupakan hal utama karena berkaitan dengan pembagian laba kepada investor atau di investasikan kembali oleh perusahaan. Suffah dan Riduwan (2016) menyatakan kebijakan keputusan pembagian dividen merupakan hal utama karena berkaitan dengan pembagian laba kepada investor yang 
menandakan semakin besarnya dividen artinya pemegang saham sejahtera. Kesejahteraan pemegang saham merupakan tujuan semua perusahaan yang dapat meningkatkan nilai perusahaan.

Nilai perusahaan meningkat sejalan dengan naiknya harga saham akibat transaksi perdagangan saham di pasar modal. Transaksi jual beli saham di pasar modal merupakan aktivitas yang dilakukan perusahaan publik untuk memperoleh dana. Faktor utama investor dalam menanam saham yaitu, dengan melihat kepada laporan keuangan. Laba perusahaan akan menjadi masukan utama bagi investor dalam mengambil keputusan untuk melakukan investasi.

Penelitian ini merupakan pengembangan penelitian dari Debby et al. (2014) dengan variabel independen meliputi kepemilikan manajerial, dewan komisaris independen, komite audit, ukuran perusahaan, dan profitabilitas. Penelitian ini dikembangkan dengan memasukkan variabel independen yaitu, kepemilikan institusional (Mukhtaruddin et al. 2014), debt to quity ratio (Gamayuni 2015), rasio likuiditas (Gamayuni 2015), dan dividend payout ratio (Gamayuni 2015). Penelitian ini mengkaitkan variabel-variabel CG, aspek ukuran perusahaan, kebijakan hutang, kinerja keuangan perusahaan, dan kebijakan dividen terhadap nilai perusahaan.

\section{Teori Keagenan}

Jensen dan Meckling (1976) keagenan adalah adanya hubungan antara principal dan agen. Hubungan antara principal dan agen terikat pada pendelegasian. Teori keagenan disebut dengan principal agent relationship karena agen bertindak atas pengaturan principal (Gitman dan Zutter 2015). Hubungan keagenan merupakan suatu kontrak yaitu satu atau lebih orang (principal) memberi delegasi (agen) untuk melakukan suatu jasa atas nama principal serta memberi wewenang kepada agen membuat keputusan yang terbaik bagi principal. Jika kedua belah pihak tersebut mempunyai tujuan yang sama untuk memaksimumkan nilai perusahaan, maka diyakini agen akan bertindak dengan cara yang sesuai dengan kepentingan principal. Jensen dan Meckling (1976) mengungkapkan teori keagenan menjelaskan bahwa terdapat asimetri informasi antara agen dengan principal. Agen mempunyai informasi lebih dari pada pemilik atau pemegang saham akan memicu adanya konflik keagenan. Moral hazard merupakan masalah asimetri informasi pada saat manajer menjalani kegiatan operasional perusahaan tanpa diketahui oleh pemegang saham atau investor sehingga manajer dapat melakukan tindakan lalai yang dapat melanggar kontrak dan secara etika tidak seharusnya dilakukan (Scott 2015).

\section{Stakeholder Theory}

Jensen (2001) menyatakan manajer sebaiknya membuat keputusan untuk memperhitungakan kepentingan semua pelaku kepentingan di perusahaan (termasuk di dalamnya tidak hanya klaim atas laporan keuangan melainkan karyawan, pelanggan, komunitas, pemerintah). Ratih dan Damayanthi (2016) menyatakan perusahaan dalam suatu usaha perlu mementingkan seluruh faktor yang berhubungan dengan kondisi perusahaan sehingga memberikan manfaat bagi stakeholder. Perusahaan dapat bertahan dan tetap ada dikarenakan adanya dukungan dari stakeholder (Putu et al. 2014). Jensen (2001) menyatakan nilai perusahaan tidak bisa meningkat jika, kepentingan stakeholder tidak terpenuhi. Dengan demikian manajemen harus memiliki kriteria untuk mengevaluasi kinerja dan memutuskan tindakan yang tepat untuk dilakukan. Kriteria yang ada diharapkan manajemen mampu meningkatkan nilai perusahaan dalam jangka waktu panjang. 


\section{Kepemilikan Manajerial dan Nilai Perusahaan}

Kepemilikan manajerial merupakan kondisi manajemen perusahaan sebagai pemilik perusahaan dimana manajemen mempunyai proporsi saham perusahaan (Ratih dan Damayanthi 2016). Proporsi kepemilikan saham yang dikontrol oleh manager dapat memberikan dampak terhadap perubahan aturan yang ada di perusahaan, kepemilikan manajerial dianggap dapat memisahkan kepentingan antara pemegang saham dan manajemen (Mukhtaruddin et al. 2014). Kepemilikan manajerial di suatu perusahaan akan mengurangi konflik antara pemegang saham dengan manajemen. Kepemilikan manajerial akan membuat manajemen lebih memperhatikan keberlangsungan perusahaan di masa yang akan datang dan memberikan dampak pada nilai perusahaan (Godfrey et al. 2010). Berdasarkan kerangka teoritis diatas mengenai faktor-faktor yang memengaruhi nilai perusahaan, maka dalam penelitian ini disusun perumusan hipotesis sebagai berikut:

$\mathrm{H}_{1}$ : Kepemilikan manajerial memiliki pengaruh terhadap nilai perusahaan

\section{Dewan Komisaris Independen dan Nilai Perusahaan}

Dewan komisaris independen adalah komisaris independen yang tidak memiliki ikatan bisnis, teman atau hubungan keluarga dengan pemegang saham maupun direksi dan pemegang saham pengendali (Sari dan Riduwan 2013). Dewan komisaris independen harus bertindak independen sehingga tidak menimbulkan conflict of interest (Azzahrah dan Yuliandhari 2014). Kehadiran komisaris independen dipercaya memberikan pengawasan dari tindakan kecurangan manajemen sehingga, pemegang saham merasa aman dan terlindungi. Dengan demikian hal ini akan menaikkan nilai perusahaan (Purbopangestu dan Subowo 2014). Berdasarkan kerangka teoritis diatas mengenai faktor-faktor yang memengaruhi nilai perusahaan, maka dalam penelitian ini disusun perumusan hipotesis sebagai berikut:

$\mathrm{H}_{2}$ : Dewan komisaris independen memiliki pengaruh terhadap nilai perusahaan

\section{Komite Audit dan Nilai Perusahaan}

Arens et al. (2014) menyatakan komite audit adalah pihak yang independen dipilih oleh dewan komisaris bertugas sebagai penghubung antara auditor dengan manajemen. Aryanti et al. (2014) menyatakan komite audit dibentuk oleh dewan komisaris yang perannya adalah mengawasi perilaku manajemen dari tindakan kecurangan dan komite audit wajib mempertahankan independensi dan menjalankan profesi sebagai auditor dengan memperhatikan kode etik akuntan profesional. Pengawasan yang dilakukan komite audit akan berdampak pada kualitas arus informasi antara pemegang saham dan manajer sehingga mampu untuk mengurangi konflik keagenan (Gill dan Obradovich 2013). Komite audit dipercaya untuk menjaga kredibilitas laporan keuangan. Komite audit dapat memberikan kontribusi terhadap objektivitas dan integritas terhadap laporan keungan sehingga, akan membantu dewan komisaris memperoleh kepercayaan dari pemegang saham. Kepercayaan yang diperoleh akan memengaruhi naiknya nilai perusahaan (Onasis dan Robin 2016). Berdasarkan kerangka teoritis diatas mengenai faktor-faktor yang memengaruhi nilai perusahaan, maka dalam penelitian ini disusun perumusan hipotesis sebagai berikut:

$\mathrm{H}_{3}$ : Komite audit memiliki pengaruh terhadap nilai perusahaan

\section{Kepemilikan Institusional dan Nilai Perusahaan}

Kepemilikan institusional adalah kepemilikan saham oleh pihak yang berbentuk institusi, seperti yayasan, bank, perusahaan asuransi, perusahaan investasi, dana pensiun, perusahaan berbentuk Perseroan Terbatas (PT) 
dan institusi lainnya. Kepemilikan institusional dianggap efektif dalam memberikan kontrol terhadap manajemen dalam suatu perusahaan. Kontrol yang baik dapat mengurangi biaya agensi sehingga dapat memaksimalkan nilai perusahaan (Rasyid 2015). Investor institusional juga dinilai mampu untuk mencegah tindakan oportunistik oleh manajer melalui pengawasan sehingga investor institusional akan berusaha menaikkan nilai perusahaan (Bernandhi dan Muid 2014). Berdasarkan kerangka teoritis diatas mengenai faktor-faktor yang memengaruhi nilai perusahaan, maka dalam penelitian ini disusun perumusan hipotesis sebagai berikut:

$\mathrm{H}_{4}$ : Kepemilikan institusional memiliki pengaruh terhadap nilai perusahaan

\section{Ukuran Perusahaan dan Nilai Perusahaan}

Ukuran perusahaan adalah skala yang dapat diklasifikasikan besar kecilnya perusahaan menurut berbagai cara perhitungan antara lain dengan total aset, log size, nilai pasar saham, dan lain-lain. Besar kecilnya ukuran perusahaan akan memengaruhi kemampuan dalam menanggung resiko yang terjadi dalam menjalankan kegiatan operasional perusahaan (Prasetyorini 2013). Umumnya ukuran perusahaan diukur dengan nilai aset (Putu et al. 2014). ukuran perusahaan dipercaya dapat meningkatkan nilai perusahaan. Besarnya ukuran perusahaan menunjukkan perusahaan mengalami perkembangan sehingga mampu memberikan sinyal positif kepada pemegang saham. Hal ini akan membuat harga saham naik dan berdampak pada meningkatnya nilai perusahaan (Sujoko dan Soebiantoro 2007). Nilai pasar saham besar akan tercermin dari besarnya ukuran perusahaan (Bernandhi dan Muid 2014). Berdasarkan kerangka teoritis diatas mengenai faktor-faktor yang memengaruhi nilai perusahaan, maka dalam penelitian ini disusun perumusan hipotesis sebagai berikut:
$\mathrm{H}_{5}$ : Ukuran Perusahaan memiliki pengaruh terhadap nilai perusahaan

\section{Debt to Equity Ratio dan Nilai Perusahaan}

Leverage mengukur kemampuan perusahaan dalam memenuhi kewajiban jangka pendek dan jangka panjang. Leverage dalam penelitian ini diukur dengan rasio DER. DER mencerminkan kemampuan perusahaan untuk memenuhi kewajiban yang perusahaan miliki dengan modal yang tersedia (Putra 2014). DER adalah rasio yang digunakan untuk mengukur hutang yang digunakan suatu perusahaan berbanding dengan modal sendiri. Semakin tinggi rasio $D E R$ maka penggunaan hutang dari pada modal sendiri akan semakin tinggi (Irayanti dan Tumbel 2014). Kebijakan pendanaan melalui hutang dapat memberikan sinyal positif bagi investor untuk berinvestasi sehingga, kebijakan hutang perusahaan memengaruhi nilai perusahaan (Samisi dan Ardiana 2013). Kebijakan hutang dapat meningkatkan nilai perusahaan jika dikelola secara optimal oleh manajemen (Sudiyatno dan Puspitasari 2010). Berdasarkan kerangka teoritis diatas mengenai faktor-faktor yang memengaruhi nilai perusahaan, maka dalam penelitian ini disusun perumusan hipotesis sebagai berikut:

$\mathrm{H}_{6}$ : Debt to equity ratio memiliki pengaruh terhadap nilai perusahaan

\section{Return on Equity dan Nilai Perusahaan}

$R O E$ termasuk komponen dari rasio profitabilitas merupakan pengukuran laba atau kesuksesan operasional pada perusahaan di suatu periode yang telah ada (Kieso et al. 2015). $R O E$ yang tinggi akan mencerminkan keberhasilan perusahaan dalam mengelola sumber daya yang dimiliki perusahaan sehingga memberikan keuntungan yang dapat dinikmati oleh investor. Peningkatan ROE sebagai indikasi adanya kenaikan laba. Kenaikan laba merupakan upaya perusahaan untuk meningkatkan kesejahteraan pemegang saham. Kenaikan laba juga disebut sebagai upaya untuk 
memaksimumkan nilai perusahaan (Setiadewi dan Purbawangsa 2015). Tingginya ROE menggambarkan prospek perusahaan yang baik sehingga dapat mendorong investor untuk meningkatkan permintaan saham. Permintaan saham yang meningkat akan menaikkan harga saham yang berdampak pada meningkatnya nilai perusahaan (Putra 2014). Berdasarkan kerangka teoritis diatas mengenai faktor-faktor yang memengaruhi nilai perusahaan, maka dalam penelitian ini disusun perumusan hipotesis sebagai berikut:

$\mathrm{H}_{7}$ : Return on equity memiliki pengaruh terhadap nilai perusahaan

\section{Likuiditas dan Nilai Perusahaan}

Subramanyam (2014) menyatakan likuiditas adalah kemampuan suatu perusahaan untuk mengkonversi aset yang dimilikinya menjadi kas. Timbuleng et al. (2015) menyatakan rasio likuiditas atau modal kerja digunakan untuk mengukur tingkat likuidnya suatu perusahaan. Likuiditas juga diartikan mengukur kemampuan perusahaan dalam memenuhi kewajiban jangka pendek dan dalam memenuhi adanya permintaan kas secara dadakan (Kieso et al. 2015). Likuiditas diukur dengan proksi current ratio menunjukkan kemampuan perusahaan dalam memenuhi kewajiban jangka pendek terhadap aset lancar. Semakin tinggi likuiditas perusahaan menandakan semakin tinggi kemampuan perusahaan untuk memenuhi kewajiban jangka pendek. Likuiditas dipercaya dapat menurunkan financial distress dan mengurangi biaya berasal dari eksternal perusahaan sehingga akan meningkatkan laba yang berpengaruh pada naiknya nilai perusahaan. Hal ini menunjukkan adanya hubungan positif signifikan terhadap nilai perusahaan (Bashir et al. 2013). Berdasarkan kerangka teoritis diatas mengenai faktor-faktor yang memengaruhi nilai perusahaan, maka dalam penelitian ini disusun perumusan hipotesis sebagai berikut:

$\mathrm{H}_{8}$ : Likuiditas memiliki pengaruh terhadap nilai perusahaan

\section{Dividend Payout ration dan Nilai Perusahaan}

Suffah dan Riduwan (2016) menyatakan kebijakan dividen (dividend policy) merupakan acuan untuk melakukan pengambilan keputusan laba yang diperoleh perusahaan pada akhir tahun yang akan dibagi kepada pemegang saham dalam bentuk dividen atau akan ditahan untuk menambah modal pembiayaan investasi di masa yang akan datang. Dividen yang dibagikan perusahaan ditentukan oleh para pemegang saham pada saat berlangsungnya Rapat Umum Pemegang Saham (RUPS). Dividen menandakan perusahaan mampu menghasilkan laba yang tinggi. Dividen yang tinggi dipercaya dapat mengembalikan modal investor sehingga membuat pemegang saham makmur (Suffah dan Riduwan 2016). Kemakmuran pemegang saham dipercaya dapat meningkatkan nilai perusahaan (Irayanti dan Tumbel 2014). Berdasarkan kerangka teoritis diatas mengenai faktor-faktor yang memengaruhi nilai perusahaan, maka dalam penelitian ini disusun perumusan hipotesis sebagai berikut:

$\mathrm{H}_{9}$ : Dividend payout ratio memiliki pengaruh terhadap nilai perusahaan

\section{METODE PENELITIAN}

Obyek yang digunakan dalam penelitian adalah perusahaan non keuangan yang terdaftar di BEl. Periode penelitian dimulai pada 2014 sampai dengan 2016. Proses pemilihan sampel menggunakan metode purposive sampling. Sampel diseleksi melalui beberapa kriteria tertentu. Sampel akhir penelitian disajikan pada tabel di bawah ini: 
Tabel 1 Hasil Pemilihan Sampel

\begin{tabular}{lcc}
\hline \multicolumn{1}{c}{ Kriteria Pemilihan Sampel } & $\begin{array}{c}\text { Jumlah } \\
\text { Perusahaan }\end{array}$ & $\begin{array}{c}\text { Jumlah } \\
\text { Data }\end{array}$ \\
\hline $\begin{array}{l}\text { Perusahaan non keuangan yang secara konsisten terdaftar } \\
\text { di BEI periode 2014 sampai dengan 2016 }\end{array}$ & 402 & 1206 \\
$\begin{array}{l}\text { Perusahaan non keuangan yang tidak menerbitkan laporan } \\
\text { keuangan yang berakhir pada tanggal 31 Desember }\end{array}$ & $(8)$ & $(24)$ \\
$\begin{array}{l}\text { Perusahaan non keuangan yang tidak menerbitkan laporan } \\
\text { keuangan dalam satuan mata uang Rupiah }\end{array}$ & $(78)$ & $(234)$ \\
$\begin{array}{l}\text { Perusahaan non keuangan yang tidak melaporkan laba } \\
\text { bersih positif secara berturut-turut }\end{array}$ & $(129)$ & $(387)$ \\
$\begin{array}{l}\text { Perusahaan non keuangan yang tidak membagikan } \\
\text { dividen secara berturut-turut }\end{array}$ & $(73)$ & $(219)$ \\
$\begin{array}{l}\text { Perusahaan non keuangan yang tidak memiliki data } \\
\text { kepemilikan manajerial dan kepemilikan institusional }\end{array}$ & $(57)$ & $(171)$ \\
\hline Jumlah sampel penelitian & 57 & 171 \\
\hline
\end{tabular}

Secara ringkas operasionalisasi variabel dapat disajikan dalam tabel 2. Operasionalisasi variabel menjelaskan mengenai definisi variabel baik dependen dan independennya beserta dengan cara pengukuran dari masing-masing variabel.

Tabel 2 Pengukuran Variabel

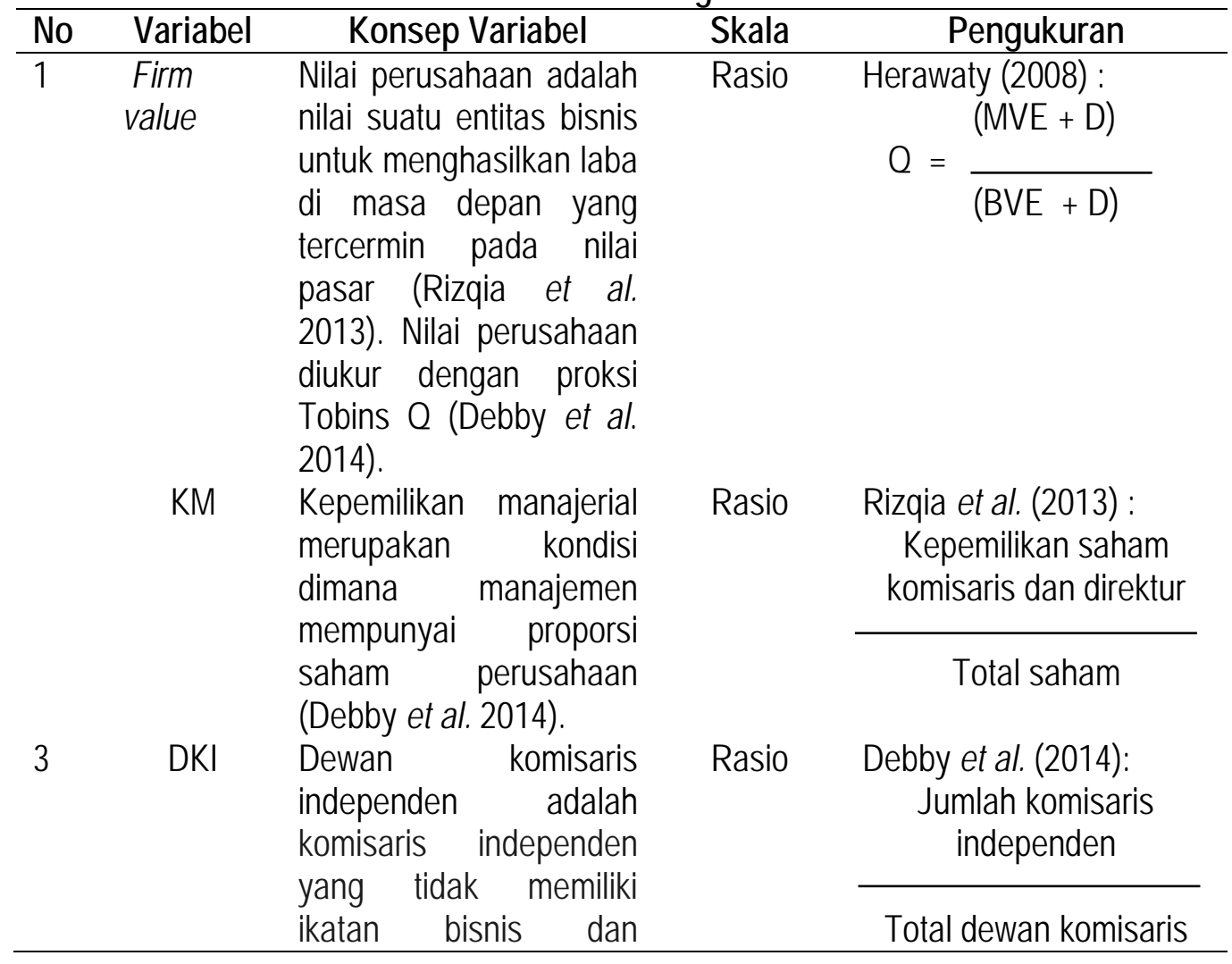




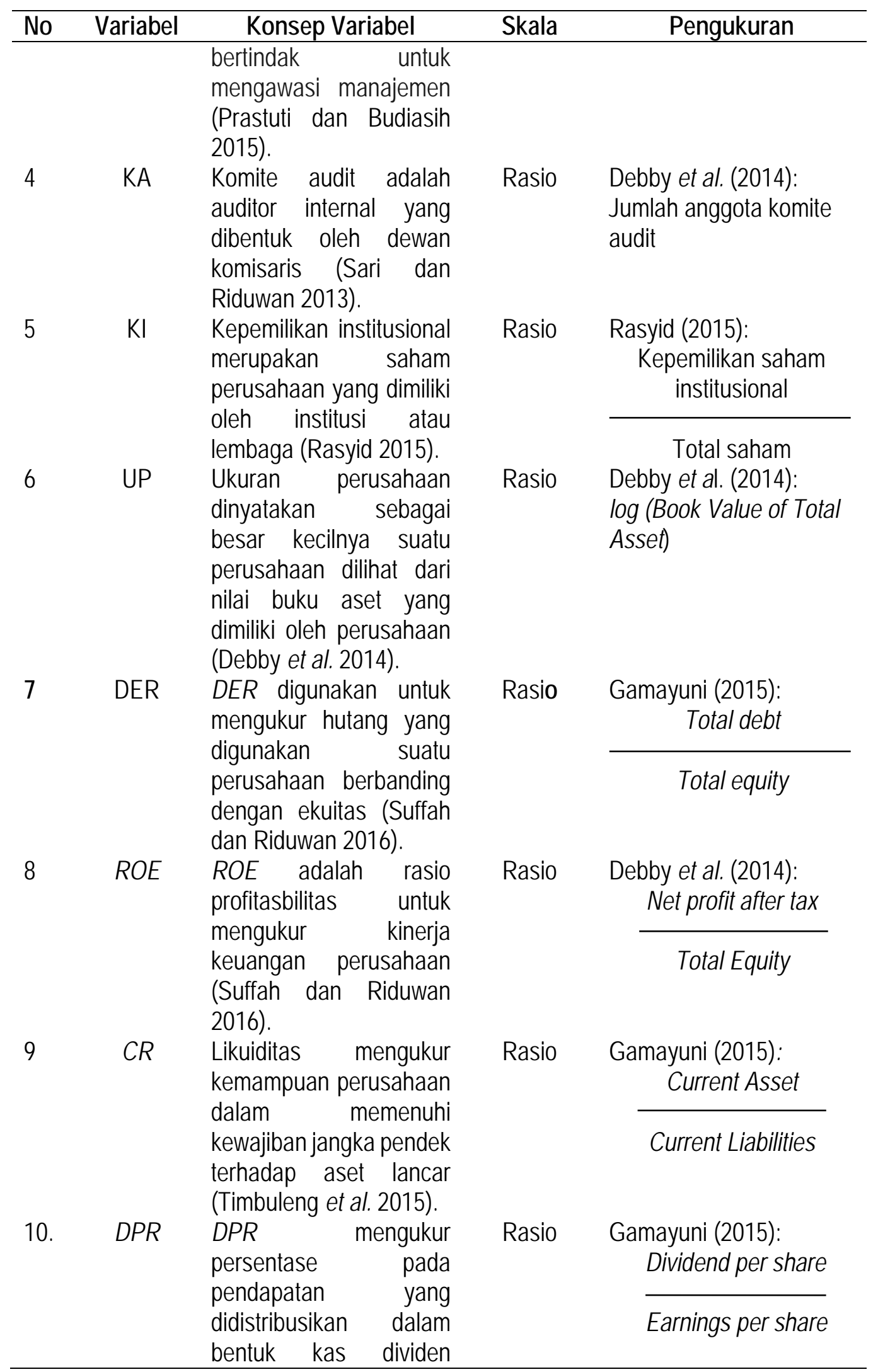




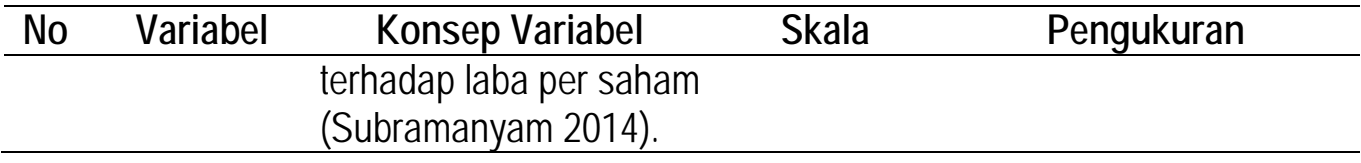

\section{HASIL PENELITIAN}

Hasil statistik deskriptif dan pengujian hipotesis dapat dilihat pada tabel berikut:

Tabel 3 Statistik Deskriptif

\begin{tabular}{ccccc}
\hline Variabel & Minimum & Maksimum & Rerata & Deviasi Standar \\
\hline Firm_Value &, 53754 & 11,08718 & 1,7841158 & 1,51292013 \\
KM &, 00000 &, 40836 &, 0322277 &, 06684946 \\
DKI &, 14286 &, 75000 &, 3880906 &, 09955637 \\
KA & 2 & 6 & 3,17 & .543 \\
KI &, 22478 &, 97495 &, 6289719 &, 16064047 \\
UP & 11,12640 & 14,41806 & 12,7218300 &, 68514827 \\
DER &, 11282 & 5,15242 & 1,0683921 &, 92808688 \\
ROE &, 00385 &, 44573 &, 1388317 &, 08174863 \\
CR &, 40111 & 15,16460 & 2,4009253 & 2,20038285 \\
DPR &, 02937 & 1,80813 &, 3396388 &, 21826824 \\
\hline
\end{tabular}

Tabel 4 Hasil Pengujian Hipotesis

\begin{tabular}{llll}
\hline Variabel & B & T & Sig. \\
\hline Konstanta & $-2,210$ & $-1,069$ &, 287 \\
KM &,- 714 &,- 455 &, 650 \\
DKI &, 187 &, 220 &, 826 \\
KA &,- 204 & $-1,234$ &, 219 \\
KI &, 241 &, 394 &, 694 \\
UP &, 194 & 1,270 &, 206 \\
DER &,- 215 & $-2,106$ &, 037 \\
ROE & 11,359 & 10,690 &, 000 \\
CR &, 067 & 1,454 &, 148 \\
DPR & 1,348 & 3,169 &, 002 \\
\hline
\end{tabular}

Hasil pengujian hipotesis menunjukkan kepemilikan manajerial (KM) memiliki nilai signifikan sebesar 0,650. Nilai siginifikansi lebih besar dari alpha $(a=0,05)$, maka dapat disimpulkan bahwa $\mathrm{Ha}_{1}$ tidak diterima. $\mathrm{Hal}$ ini menggambarkan kepemilikan manajerial tidak memiliki pengaruh signifikan terhadap nilai perusahaan. Hasil pengujian ini sejalan dengan penelitian Wida dan Suartana (2014), Debby et al. (2014), Rustan et al. (2014) yang menyatakan tidak terdapat pengaruh kepemilikan manajerial terhadap nilai perusahaan.

Sebagaimana teori keagenan menyatakan kepemilikan manajerial dianggap mampu menyetarakan kepentingan manajemen dan pemegang saham dikarenakan adanya kepemilikan saham manajemen akan memaksimalkan kinerja perusahaan untuk mencapai tujuan antara pemegang saham dan 
manajemen (Sofyaningsih dan Hardiningsih 2011). Namun, kepemilikan manajerial dianggap belum mampu mengurangi masalah keagenan dikarenakan manajemen masih fokus pada tujuannya sendiri (Wida dan Suartana 2014). Manajemen tidak memiliki motivasi untuk meningkatkan kinerja perusahaan yang berdampak pada naiknya nilai perusahaan dikarenakan memiliki jumlah saham perusahaan yang sedikit. Hal ini membuat manajemen tidak terlalu mementingkan kemajuan perusahaan karena tidak ada rasa kepemilikan terhadap perusahaan (Purbopangestu dan Subowo 2014).

Hasil pengujian hipotesis menunjukkan dewan komisaris independen (DKI) memiliki nilai signifikan sebesar 0,826. Nilai signifikansi lebih besar dari alpha $(\alpha=0,05)$, maka dapat disimpulkan bahwa $\mathrm{Ha}_{2}$ tidak diterima. Hal ini menunjukkan adanya dewan komisaris independen tidak memberikan pengaruh signifikan terhadap nilai perusahaan. Hasil penelitian ini sejalan dengan Prastuti dan Budiasih (2015), Carningsih (2009), Debby et al. (2014) yang menyatakan DKI tidak berpengaruh terhadap nilai perusahaan. DKI dianggap kurang efektif dalam menjalankan fungsinya untuk mengawasi tindakan manajemen. Proporsi DKI juga belum mampu memberikan efek dominan terhadap setiap kebijakan dewan komisaris (Prastuti dan Budiasih 2015). DKI juga belum bertindak secara independen dalam monitoring kebijakan manajemen (Carningsih 2009). Hal ini menggambarkan DKI belum berhasil melindungi kepentingan pemegang saham terhadap tindakan oportunistik manajemen.

Hasil pengujian hipotesis menunjukkan komite audit (KA) memiliki nilai signifikan sebesar 0,219 . Nilai signifikansi lebih besar dari alpha $(\alpha=0,05)$, maka dapat disimpulkan bahwa $\mathrm{Ha}_{3}$ tidak diterima. Komite audit tidak memiliki pengaruh signifikan terhadap nilai perusahaan. Hasil penelitian ini sejalan dengan Wardoyo dan Veronica (2013), Siahaan (2013), Sari dan
Ardiana (2014) yang menyatakan komite audit tidak berpengaruh terhadap nilai perusahaan.

Komite audit dianggap belum mampu menjalankan perannya dalam mengawasi proses pelaporan keuangan perusahaan secara efektif sehingga tujuan untuk mewujudkan laporan keuangan yang disusun secara integritas dan objektifitas oleh auditor belum tercapai (Prastuti dan Budiasih 2015). Hal ini akan membuat investor mempertimbangkan kembali akan keandalan laporan keuangan. Laporan keuangan yang kualitas dan keandalannya diragukan akan menurunkan minat investor untuk berinvestasi yang berakibat adanya penurunan harga saham dan berdampak pada penurunan nilai perusahaan (Purbopangestu dan Subowo 2014). Hal ini menunjukkan hadirnya komite audit dalam perusahaan juga tidak menjamin kinerja perusahaan lebih baik (Siahaan 2013). Kehadiran komite audit hanya dianggap sebagai pemenuhan regulasi perusahaan (Wardoyo dan Veronica 2013).

Hasil pengujian hipotesis menunjukkan kepemilikan institusional (KI) memiliki nilai signifikan sebesar 0,694. Nilai signifikansi lebih besar dari alpha $(a=0,05)$, maka dapat disimpulkan bahwa $\mathrm{Ha}_{4}$ tidak diterima. Hasil tersebut menunjukkan $\mathrm{KI}$ tidak memiliki pengaruh signifikan terhadap nilai perusahaan. Penelitian ini sejalan dengan Bernandhi dan Muid (2014) yang menyatakan KI tidak berpengaruh terhadap nilai perusahaan.

Investor institusional belum cukup efektif dalam memonitor kinerja manajer. Segala keputusan dan kebijakan masih didominasi oleh manajer. Keterbatasan untuk mengaskes dalam pengendalian manajer membuat tidak adanya implikasi kepemilikan institusional terhadap nilai perusahaan (Bernandhi dan Muid 2014). Tindakan manajemen oportunistik dan adanya kompromi dengan pemegang saham mayoritas yaitu pihak investor institusional mengakibatkan perusahaan ditanggapi negatif oleh pasar saham. Tanggapan pasar yang negatif akan 
merugikan perusahaan dengan turunnya harga saham perusahaan tersebut sehingga dengan kepemilikan institusional belum mampu meningkatkan nilai perusahaan (Purbopangestu dan Subowo 2014).

Hasil pengujian hipotesis menunjukkan ukuran perusahaan (UP) memiliki nilai signifikan sebesar 0,206 . Nilai signifikansi lebih besar dari alpha $(\alpha=0,05)$, maka dapat disimpulkan bahwa $\mathrm{Ha}_{5}$ tidak diterima. Hasil tersebut menunjukkan UP tidak berpengaruh signifikan terhadap nilai perusahaan. Penelitian ini sejalan dengan Dewi dan Wirajaya (2013), Setiadewi dan Purbawangsa (2015) yang menyatakan tidak berpengaruhnya ukuran perusahaan terhadap nilai perusahaan. Hal ini berarti UP bukan faktor utama yang dapat dijadikan acuan investor dalam investasinya, melainkan terdapat faktor lainnya yang dapat dijadikan acuan utama untuk menilai suatu perusahaan. Hal ini menunjukkan ukuran perusahaan tidak menjamin tingginya nilai perusahaan. Perusahaan besar belum membuat keputusan untuk melakukan ekspansi sebelum seluruh kewajiban yang dimiliki telah dipenuhi sehingga tidak adanya pengembangan usaha yang dapat menarik minat investor untuk berinvestasi (Setiadewi dan Purbawangsa 2015).

Hasil pengujian hipotesis menunjukkan debt to equity ratio (DER) memiliki nilai signifikan sebesar 0,037 . Nilai signifikansi lebih kecil dari alpha $(\alpha=0,05)$, maka dapat disimpulkan bahwa $\mathrm{Ha}_{6}$ diterima. Hal ini berarti DER memiliki pengaruh signifikan terhadap nilai perusahaan dengan arah negatif. Semakin tingginya $D E R$ akan menurunkan nilai perusahaan. Penelitian ini sejalan dengan Bernandhi dan Muid (2014), Dewi dan Wirajaya (2013) yang menyatakan $D E R$ berpengaruh terhadap nilai perusahaan dengan arah negatif.

Nilai $D E R$ pada titik dibawah optimal dapat memberikan pengaruh naiknya nilai perusahaan. Sebaliknya, DER yang melebihi batas optimal akan menurunkan nilai perusahaan (Dewi dan Wirajaya 2013).
Perusahaan untuk memperoleh kredit diperlukan biaya yang tinggi. Cost of capital tinggi karena struktur modal yang dibiayai dana hutang tinggi. Biaya bunga berasal dari hutang yang tinggi akan meningkatkan risiko hutang perusahaan. Jika biaya yang telah dikeluarkan tidak sebanding dengan keuntungan yang diperoleh, perusahaan akan berdampak kerugian sehingga akan mengurangi minat investor untuk investasi (Sujoko dan Soebiantoro 2007). Tingkat kebijakan hutang yang tinggi juga diartikan perusahaan tidak cukup optimal dalam mengelola struktur pendanaan perusahaan yang akan berdampak pada penurunan nilai perusahaan (Bernandhi dan Muid 2014).

Hasil pengujian hipotesis menunjukkan return on equity $(R O E)$ memiliki nilai signifikan sebesar 0,000 . Nilai signifikansi lebih kecil dari alpha $(\alpha=0,05)$, maka dapat disimpulkan bahwa $\mathrm{Ha} 7$ diterima. Hal ini berarti ROE memiliki pengaruh positif signifikan terhadap nilai perusahaaan dengan arah positif. Hasil penelitian ini sejalan dengan Debby et al. (2014), Wardoyo dan Veronica (2013), Putra (2014), dan Rasyid (2015) yang menyatakan ROE berpengaruh positif terhadap nilai perusahaan.

Hal ini menunjukkan semakin tinggi ROE akan meningkatkan nilai perusahaan. Keuntungan yang meningkat dalam suatu perusahaan akan menunjukkan prospek yang baik pada masa yang akan datang (Sujoko dan Soebiantoro 2007). ROE dinilai dapat menghasilkan keuntungan bagi pemegang saham sehingga mendorong minat investor untuk berinvestasi. Nilai $R O E$ yang tinggi juga dapat dijadikan tolok ukur bahwa perusahaan telah mampu memberikan tingkat pengembalian modal. Laba yang tinggi akan berdampak pada peningkatan $R O E$ sehingga memberikan sinyal positif bagi pemegang saham untuk keputusan berinvestasi (Rasyid 2015). Sebagaimana teori stakeholder menyatakan kepentingan stakeholder yang terpenuhi akan meningkatkan kinerja perusahaan sehingga akan berdampak 
pada meningkatnya nilai perusahaan (Jensen 2001).

Hasil pengujian hipotesis $t$ variabel likuiditas dengan proksi current ratio (CR) memiliki nilai signifikan sebesar 0,148 . Nilai signifikansi lebih besar dari alpha $(a=0,05)$, maka dapat disimpulkan bahwa $\mathrm{Ha}_{8}$ tidak diterima. Hal ini menunjukkan likuiditas tidak memiliki pengaruh signifikan terhadap nilai perusahaan. Penelitian ini sejalan dengan Timbuleng et al. (2015), Winarto (2015), dan Nurhayati (2013). Likuiditas bukan faktor yang memberikan pengaruh terhadap naiknya nilai perusahaan dikarenakan likuiditas yang tinggi tidak menjamin peningkatan kinerja perusahaan. Jika jumlah aset lancar lebih tinggi dibanding aset tetap menandakan perusahaan tersebut tidak banyak memilki aset tetap dalam jangka waktu panjang. Aset tetap perusahaan dapat dijadikan sebagai investasi perusahaan dan jaminan kredit. Perihal aset lancar yang tinggi hanya dapat menjamin sustainability perusahaan dalam jangka waktu pendek saja (Timbuleng et al. 2015). Tingginya likuiditas tidak dapat dijadikan faktor penentu prospek kedepan bagi perusahaan. Likuiditas hanya mengukur kemampuan perusahaan dalam memenuhi kewajiban jangka pendek terhadap aset lancar yang dimiliki. Hal ini menunjukkan likuiditas tidak dilihat investor dalam keputusan investasi (Nurhayati 2013).

Hasil pengujian hipotesis menunjukkan dividend payout ratio (DPR) memiliki nilai signifikan sebesar 0,002. Nilai signifikansi lebih kecil dari alpha $(a=0,05)$, maka dapat disimpulkan bahwa Hag diterima. Hal ini berarti DPR memiliki pengaruh signifikan terhadap nilai perusahaan dengan arah positif. Hasil penelitian ini sejalan dengan Rizqia et al. (2013), Bashir et al. (2013), Gamayuni (2015), Suffah dan Riduwan (2016) yang menyatakan DPR berpengaruh terhadap nilai perusahaan dengan arah yang positif.

Peningkatan DPR direspon dengan baik oleh investor sehingga peningkatan DPR dapat menaikkan nilai perusahaan. Hal ini menunjukkan investor lebih menyukai pembagian dividen kas dibandingkan dengan capital gain (Mayogi dan Fidiana 2016). DPR yang tinggi menandakan perusahaan mampu menghasilkan laba dan memberikan kesejahteraan bagi pemegang saham. Kesejahteraan terjadi dikarenakan perusahaan mampu membagikan dividen yang merupakan bentuk pengambalian kepada investor (Suffah dan Riduwan 2016).

\section{PENUTUP}

Faktor-faktor yang menjadi acuan investor dalam mengambil keputusan untuk investasi adalah tingkat pengembalian modal. Hasil pengujian hipotesis menunjukkan perhatian utama investor dalam keputusan investasi adalah aspek yang terkait dengan kemampuan perusahaan menciptakan laba. hal ini ditunjukkan dengan aspek seperti $R O E$ dan $D P R$ yang berpengaruh terhadap nilai perusahaan dengan arah positif. Aspek terkait dengan laba merupakan perhatian utama bagi investor dalam keputusan investasinya. Semakin tinggi minat investor untuk berinvestasi pada perusahaan tersebut akan meningkatkan permintaan saham. Peningkatan permintaan saham akan berdampak pada naiknya harga saham sehingga berdampak pada naiknya nilai perusahaan. DPR dan ROE juga mencerminkan prospek perusahaan dalam jangka panjang terhadap nilai perusahaan. Berbeda halnya dengan $D E R$ (kebijakan hutang) disaat nilai $D E R$ meningkat akan berdampak pada penurunan nilai perusahaan. Hal ini menunjukkan pengelolaan dana hutang belum optimal dan perusahaan belum mampu menjaga kestabilan kondisi keuangannya. Perusahaan juga dinilai belum mampu meminimalisasi risiko yang dapat timbul akibat besarnya hutang yang dimiliki. Aspek lain yang tidak terkait dengan laba tidak ditemukan mempengaruhi nilai perusahaan dikarenakan aspek lain tidak terkait dengan 
profitabilitas dan menjadi acuan bagi investor dalam keputusan berinvestasi. Aspek lain juga dinilai hanya sebagai cerminan prospek perusahaan dalam jangka pendek saja terhadap nilai perusahaan. Penciptaan dan peningkatan nilai perusahaan pada waktu akan datang memerlukan kinerja keuangan yang baik dan implementasi CG perusahaan yang baik.

Penelitian ini memiliki beberapa kekurangan dan keterbatasan, yaitu pertama, penelitian ini hanya mengambil sampel selama tiga tahun yaitu dari periode 2014 sampai dengan 2016. Kedua, penelitian ini hanya menggunakan 9 variabel independen yaitu, pada (i) aspek GCG: kepemilikan manajerial, dewan komisaris independen, komite audit, kepemilikan institusional (ii) aspek karakterisitik perusahaan: ukuran perusahaan (iii) aspek kinerja keuangan: debt to equity ratio (DER), dividend payout ratio (DPR), return on equity (ROE), dan likuiditas (CR).
Rekomendasi yang dapat diberikan pada penelitian selanjutnya berdasarkan keterbatasan penelitian yaitu pertama, pemperpanjang periode penelitian baik menambah periode penelitian sebelum dan sesudah periode penelitian sehingga dapat memberikan hasil penelitian yang lebih menyeluruh. Kedua, nilai perusahaan dapat dianalis dengan aspek lainnya yang berkaitan dengan nilai perusahaan pada (i) aspek CG seperti indikator lainnya, jumlah rapat komite audit, jumlah kehadiran dewan komisaris dalam rapat, jumlah kehadiran komite audit, dan lainlain (ii) aspek karakteristik perusahaan seperti umur perusahaan, strategi perusahaan, dan lain-lain (iii) aspek kinerja keuangan seperti rasio aktivitas dan lain-lain. Penambahan variabel lainnya diharapkan dapat memberikan pengaruh terhadap nilai perusahaan dan hubungan antara variabel lebih kuat.

\section{REFERENSI:}

Arens, Alvin A, Randal J. Elder, \& Mark S. Beasley. 2014. Auditing and Assurance Service - An Integrated Approach.14th Edition.Pearson Education Limited, Edinburg UK.

Aryanti, Novi, Kania Nurcholisah, dan Diamonalisa Sofiyanty. 2014. Pengaruh Mekanisme Good Corporate Governance terhadap Kinerja Perusahaan dan Nilai perusahaan. Prosiding Akuntansi. http://karyailmiah.unisba.ac.id/index.php/akuntansi/article/view/1793/pdf (diakses 31 Maret 2017).

Azzahrah, Zantisya \& Willy S Yuliandhari. 2014. Pengaruh Mekanisme Good Corporate Governance terhadap nilai perusahaan. E-Proceeding of Management, 1(3), 203-213.

Bashir, Hamid, Khurram Suktan, \& Omar Khazaal Jghef. 2013. Impact of Derivatives Usage on Firm Value: Evidence from Non Financial Firms on Pakistan. Journal of Management Research, 5(4), 118-127.

Bernandhi, Riza \& Abdul Muid. 2014. Pengaruh Kepemilikan Manajerial, Kepemilikan Institusional, Kebijakan Dividen, Leverage, Dan Ukuran Perusahaan Terhadap Nilai Perusahaan. Diponegoro Journal of Accounting, 3(1), 1-14.

Carningsih. 2009. Pengaruh Good Corporate Governance Terhadap Hubungan Antar Kinerja Keuangan Dengan Nilai Perusahaan. Jurnal Akuntansi Universitas Gunadarma, http://www.gunadarma.ac.id/ibrary/articles/graduate/economy/2009/Artikel_20205242.pdf (diakses 31 Maret 2017).

Debby, Julia Farah, Mukhtaruddin, Emylia Yuniarti, Dewa Saputra, \& Abukosim. 2014. Good Corporate Governance, Company's Characteristic and Firm Value: Empirical Study of Listed Banking on Indonesian Stock Exchange. Journal on Bussiness, 3(4), 81-88.

Dewi, Ayu Sri Mahatma \& Ary Wirajaya. 2013. Pengaruh Struktur Modal, Profitabilitas, Ukuran Perusahaan pada Nilai Perusahaan. E-Jurnal Akuntansi Universitas Udayana. 4(2), 358-372. 
Gamayuni, Rindu Rika. 2015. The Effect of Intagible Asset, Financial Perfomance and Financial Policies on The Firm Value. International Journal of Scientific, 4(1), 202-212.

Gill, Amarjit \& John D. Obradovich. 2013. The Impact of Corporate Governance and Financial Leverage on the Value of American Firms. International Research Journal of Finance and Economics, 91, 1-14.

Gitman, Lawrence J., \& Chad J. Zutter. 2015. Principles of Managerial Finance, 14th Edition. Boston: Pearson Education.

Godfrey, Jayne, Allan Hodgson, Ann Tarca, Jane Hamilton, \& Scott Holmes. 2010. Accounting Theory. Seventh Edition, John Wiley \& Sons Australia

Herawaty, Vinola. 2008. Peran Praktek Corporate Governance Sebagai Moderating Variabel dari Pengaruh Earnings Management. Jurnal Akuntansi dan Keuangan, 10(2), 97-108.

Irayanti, Desi \& Altje L. Tumbel. 2014. Analisis Kinerja Keuangan Pengaruhnya Terhadap Nilai Perusahaan Pada Industri makanan dan Minuman di BEl. Jurnal EMBA, 2(3), 1473-1482.

Jensen, Michael C. \& William H. Meckling. 1976. Theory of The Firm: Managerial Behavior, Agency Cost and Ownership Structure. Journal of Financial Economics, 3(4), 305-360.

Jensen, Michael C. 2001. Value Maximization, Stakeholder Theory, and the Corporate Objective Function. Journal of Applied Corporate Finance, http://papers.ssrn.com/abstract_id=220671 (diakses 01 November 2017).

Kieso, Donald E., Jerry J. Weygandt, \& Paul D. Kimmel. 2015. Financial Accounting. United Stated of America: John Wiley \& Sons Inc.

Mardiyati, Umi, Gatot Nazir Ahmad \& Ria Putri. 2012. Pengaruh Kebijakan Dividen, Kebijakan Hutang dan Profitabilitas Terhadap Nilai Perusahaan Manufaktur yang Terdaftar Di Bursa Efek Indonesia (Bei) Periode 2005-2010. Jurnal Riset Manajemen Sains Indonesia, 3(1), 1-17.

Mayogi, Dien Gusti \& Fidiana. 2016. Pengaruh Profitabilitas, Kebijakan Dividen dan Kebijakan Utang Terhadap Nilai Perusahaan. Jurnal IImu dan Riset Akuntansi, 5(1), 1-18.

Moniaga, Fernandes. 2013. Struktur Modal Profitabilitas dan Struktur Biaya Terhadap Nilai Perusahaan. Jurnal EMBA, 1(4), Desember, 433-442.

Muktharuddin, Relasari, \& Messa Felmania. 2014. Good Corporate Governance Mechanism, Corporate Social Responsibility Disclosure on Firm Value: Empirical Study on Listed Company in Indonesia Stock Exchange. International Journal of Finance \& Accounting Studies, 2(1), 1-10.

Nurhayati, Mafizatun. 2013. Pengaruh Kebijakan Perusahaan Terhadap Nilai Perusahaan dengan Kinerja Perusahaan Sebagai Variabel Intervening. Jurnal Keuangan dan Bisnis, 5(2), 144-153.

Onasis, Kristie dan Robin. 2016. Pengaruh Tata Kelola Perusahaan Terhadap Nilai Perusahaan Pada Perusahaan Sektor Keuangan yang Terdaftar Di BEl. E-Jurnal Akuntansi, 20(1), 1-22

Prasetyorini, Bhekti Fitri. 2013. Pengaruh Ukuran Perusahaan, Leverage, Price Earning, Ratio Dan Profitabilitasnya Terhadap Nilai Perusahaan. Jurnal IImu manajemen, 1(1), 183-196.

Prastuti, Ni ketut Karlina, \& I Gusti Ayu Nyoman Budiasih. 2015. Pengaruh Good Corporate Governance Pada Nilai Perusahaan Dengan Moderasi Corporate Social Responsibility. E-Jurnal Akuntansi Universitas Udayana 13(1), 114-129.

Purbopangestu, Hary Wisnu \& Subowo, 2014. Pengaruh Good Corporate Governance Terhadap Nilai Perusahaan Dengan Corporate Social Responsibility Sebagai variabel Intervening. Accounting Analyis Journal, http://journal.unnes.ac.id/sju/index.php/aaj (Diakses 05 Mei 2017).

Putra, Nyoman Wedana Adi. 2014. Pengaruh Faktor Fundamental Pada Nilai Perusahaan Sektor Telekomunikasi Di Bursa Efek Indonesia. E-Jurnal Akuntansi Universitas Udayana, 8(3), 385-407.

Putu, Ni Nyoman G Martini Putu, Moeljadi, Djumadir and Atim Djazuli. 2014. Factor Affecting Firms Value of Indonesia Public Manufacting Firms. International Journal of Bussiness and Managment Invention, 3(2), 35-44.

Rasyid, Abdul. 2015. Effect of Ownership, Capital Structure, Profitability and Company's Growth toward Firm Value. International Journal of Bussiness and Management invention, 4(4), 25-31. 
Ratih, I Dewa Ayu, I Gusti Ayu Eka Damayanthi, 2016. Kepemilikan Manajerial Dan Profitabilitas Pada Nilai perusahaan, Dengan Pengungkapan Tanggung Jawab Sosial Sebagai Variabel Pemoderasi. E-Jurnal Akuntansi Universitas Udayana, 14(2), 1510-1538.

Rizqia, Dwita Ayu, Siti Aisjah, \& Sumiati. 2013. Effect of Managerial Ownership, Financial Leverage, Profitability, Firm Size, and Investment Opportunity on Dividend Policy and Firm Value. Research Journal of Finance and Accounting. 4(11): $120-130$.

Rompas, Gisela Prisilia. 2013. Likuiditas Solvabilitas, dan Rentabilitas Terhadap Nilai Perusahaan BUMN yang Terdaftar yang terdaftar Di Bursa Efek Indonesia. Jurnal EMBA, 1(3), 252-262.

Rustan, Darwin Said, \& Yohanis Yura. 2014. Pengaruh Struktur Kepemilikan Terhadap Nilai Perusahaan: Kualitas Laba dan Kebijakan Laba dan Kebijakan Hutang Sebagai Variabel Intervening. Jurnal Analisis, 3(1), 3239.

Samisi, Komang dan Putu Agus Ardiana. 2013. Pengaruh Struktur Pendanaan Terhadap Nilai Perusahaan Dengan Kempemilikan Manajerial Sebagai Variabel Moderasi. E-Jurnal Akuntansi Universitas Udayana, 5(2), 451469.

Sari, A.A Pt. Agung Mirah Purnama \& Putu Agus Ardiana. 2014. Pengaruh Board Size Terhadap Nilai Perusahaan. E-Jurnal Akuntansi Universitas Udayana, 7(1), 177-191.

Sari, Enggar Fibria Verdana dan Akhmad Riduwan. 2013. Pengaruh Corporate Governance terhadap Nilai Perusahaan: Kualitas Laba sebagai Variable Intervening. Jurnal IImu dan Riset Akuntansi, 1(1), 1-20.

Scott, William R. 2015. Financial Accounting Theory. United States of America: Pearson Canada Inc.

Setiadewi, Kadek Ayu Yogamurti \& Ida Bgs. Anom Purbawangsa. 2015. Pengaruh Ukuran Perusahaan dan Leverage Terhadap Profitabilitas dan Nilai Perusahaan. E-Jurnal Akuntansi, https://ojs.unud.ac.id/index.php/Manajemen/article/view/11087Setiadewi (diakses 30 Oktober 2017).

Siahaan, Fadjar O.P. 2013. The Effect of Good Corporate Governance Mechanism Leverage, and Firm Size on Firm Value. Journal on Business Review, 2(4), 137-142.

Sofyaningsih, Sri \& Pancawati Hardiningsih. 2011. Struktur Kepemilikan, Kebijakan Dividen, Kebijakan Utang Dan Nilai Perusahaan. Dinamika Keuangan dan Perbankan, 3(1), 68-87.

Subramanyam, K. R. 2014. Financial Statement Analysis. New York: McGraw-Hill Education.

Sudiyatno, Bambang \& Elen Puspitasari. 2010. Pengaruh Kebijakan Perusahaan Terhadap Nilai Perusahaan dengan Kinerja Perusahaan Sebagai Variabel Intervening. Dinamika Keuangan dan Perbankan, 2(1), 122.

Suffah, Rofiqotus \& Akhmad Riduwan. 2016. Pengaruh Profitabilitas, Leverage, Ukuran Perusahaan Dan Kebijakan Dividen Pada Nilai Perusahaan. Jurnal IImu dan Riset Akuntansi, 5(2), 1-17.

Sujoko, \& Ugy Soebiantoro. 2007. Pengaruh Struktur Kepemilikan Saham, Faktor Intern Dan Faktor Ekstern Terhadap Nilai Perusahaan. Jurnal Manajemen dan Kewirausahaan, 9(1), 41-48

Timbuleng, Ferlen, Sientje C.Nangoy, \& Ivonne S. Saerang. 2015. Pengaruh faktor Likuiditas, Leverage, NPM, dan ROI Terhadap Nilai perusahaan. Junal EMBA, 3(2), 546-557

Wardoyo, \&Theodora Martina Veronica. 2013. Pengaruh Good Corporate Governance, Corporate Social Responsibility \& Kinerja Keuangan Terhadap Nilai Perusahaan. Jurnal Dinamika Manajemen, 4(2), 132149.

Wida, Ni Putu \&l Wayan Suartana. 2014. Pengaruh Kepemilikan Manajerial dan Kepemilikan Institusional pada Nilai perusahaan. E-Jurnal Akuntansi Universitas Udayana, 9(3), 575-590.

Winarto, Jacinta. 2015. The Determinants of Manufacturer Firm Value in Indonesia Stock Exchange. International Journal of information, Business and Management, 7(4), 322-349. 
